\section{Fertilizer Composition, Concentration, and Irrigation Method Affect Growth and Development of Oxalis regnellii and $O$. triangularis}

\author{
Chad T. Miller ${ }^{1}$, Neil S. Mattson, and William B. Miller \\ Department of Horticulture, Cornell University, 159 Plant Science Building, \\ Ithaca, NY 14853
}

Additional index words. floriculture, subirrigation, drip irrigation, control release fertilizer, shamrock plant

\begin{abstract}
Oxalis regnellii, the shamrock plant, and $\boldsymbol{O}$. triangularis are niche ornamental greenhouse crops produced and marketed primarily for their foliage; thus, it is imperative to produce the fullest, most colorful, and blemish-free plants as possible. An experiment was conducted using $O$. regnellii, comparing two irrigation methods, overhead (drip) irrigation versus subirrigation, in addition to varying $20 \mathrm{~N}-2.2 \mathrm{P}-16.6 \mathrm{~K}$ fertilizer concentrations, 50, 100, 200, 300, and $500 \mathrm{mg} \cdot \mathrm{L}^{-1}$ nitrogen $(\mathrm{N})$. Overhead irrigation produced larger plants with increased root mass as compared with subirrigation. Low or high fertilizer concentration $\left(50 \mathrm{mg} \cdot \mathrm{L}^{-1} \mathrm{~N}\right.$ and $500 \mathrm{mg} \cdot \mathrm{L}^{-1} \mathrm{~N}$, respectively) led to reductions in the fresh and dry weight of overhead-irrigated plants compared with intermediate fertilizer rates. At the highest fertilizer treatment, plant height was decreased. Chlorophyll index (based on SPAD readings) increased linearly and quadratically for subirrigated and overhead-irrigated plants, respectively. A second study analyzed the effects of seven different fertilizer formulations on growth of $O$. regnellii and $O$. triangularis. The fertilizers used in this study were Jack's LX All Purpose (21N-2.2P-16.6K), Peter's Professional (20N-8.8P-16.6K), Jacks Poinsettia FeED Ca-Mg (15N-1.7P-12.5K), Jack's Petunia FeED Mg (20N-1.3P-15.7K), Peter's Professional Peat-Lite Dark Weather Feed (15N-0P-12.5K), Peter's Excel Cal-Mag (15N-2.2P-12.5K), and the slow-release fertilizer Osmocote $^{\circledR}(14 \mathrm{~N}-4.2 \mathrm{P}-11.6 \mathrm{~K})$. Growth of both species was significantly reduced by fertilizers that contained little or no phosphorus (P). Current water-soluble fertilizer recommendations of $21 \mathrm{~N}-2.2 \mathrm{P}-16.6 \mathrm{~K}$ or slow-release granule fertilizer of $14 \mathrm{~N}-4.2 \mathrm{P}$ 11.6K (Osmocote ${ }^{\circledR}$ ) produced acceptable, marketable plants, whereas the best $O$. regnellii and $O$. triangularis plants were produced using $15 \mathrm{~N}-2.2 \mathrm{P}-12.5 \mathrm{~K}$ and $20 \mathrm{~N}-1.3 \mathrm{P}-15.7 \mathrm{~K}$ formulations, likely as a result of the additional calcium (Ca), magnesium (Mg), and iron (Fe) in the mixtures.
\end{abstract}

Oxalis regnellii, the shamrock plant, is a niche crop produced primarily for the St. Patrick's Day holiday (De Hertogh and Le Nard, 1993; Dole and Wilkins, 2005). Fertilization recommendations for oxalis are limited. De Hertogh and Le Nard (1993) recommend using $14 \mathrm{~N}-4.2 \mathrm{P}-11.6 \mathrm{~K}$ Osmocote ${ }^{\circledR}$ (no rate specified) after visible growth or a weekly liquid application of $200 \mathrm{mg} \cdot \mathrm{L}^{-1} \mathrm{~N}$ of $20 \mathrm{~N}-$ $8.8 \mathrm{P}-16.6 \mathrm{~K}$ in the irrigation water. Leaf chlorosis has been reported during greenhouse production and has been hypothesized to be Fe deficiency (De Hertogh, 1996; De Hertogh and Le Nard, 1993; Dole and Wilkins, 2005; Hammer, 2006). Iron deficiency is a common disorder that affects many plant species and is often the first micronutrient that becomes limiting in greenhouse media as $\mathrm{pH}$ rises (Nelson, 1994). In addition to high substrate $\mathrm{pH}$, another potential cause of Fe deficiency is poor root system growth attributable to

Received for publication 22 Nov. 2010. Accepted for publication 26 Apr. 2011.

${ }^{1}$ To whom reprint requests should be addressed; e-mail ctmiller@ksu.edu. used in the greenhouse industry and each system has advantages and limitations. A major advantage to overhead irrigation compared with subirrigation is the ability to control soluble salt levels through leaching. Overhead drip irrigation and boom watering systems, as compared with hand watering, can also reduce labor costs and can improve efficiency of water delivery (Hall, 1980; Harbaugh et al., 1986). Major drawbacks to overhead irrigation, particularly hand irrigation, include labor costs and the potential for poor water use efficiency. Another drawback to overhead irrigation is the potential for unsightly mineral residue on foliage from fertilizer applications, compromising crops marketed primarily for their foliage characteristics such as oxalis. Other drawbacks to overhead irrigation include potential for clogged emitters, increased susceptibility for foliar diseases, and foliage deflecting water, reducing penetration to the media.

Like with overhead irrigation, there are positive and negative implications associated with subirrigation (e.g., ebb and flow, tray, trough, floor flooding). There is the potential to reduce labor costs because many plants can be irrigated at the same time and often with the push of a button. Subirrigation also has the potential to improve water and fertilizer use efficiency (Dole et al., 1994; Holcomb et al., 1992; Uva et al., 1998) because the irrigation water is often collected and recirculated, reducing input costs (i.e., fertilizer) and reducing runoff and nutrient leaching. Currently, with increasing social concerns regarding water use and nutrient runoff, it is imperative to conduct, at minimum, small-scale trials to determine efficient but effective irrigation practices for individual species. Another benefit to subirrigation is reduced susceptibility for foliar diseases with little to no water contacting the foliage. However, there is an increased risk for spread of disease between plants, particularly soilborne pathogens, when using an ebb and flood system with recirculated water. A major production challenge with subirrigation is that soluble salts can accumulate, because leaching does not occur (Kang et al., 2004), which can reduce plant growth and development (Todd and Reed, 1998). The costs associated with installing or retrofitting a greenhouse can also be a limiting factor for implementing subirrigation.

Greenhouse fertilization of floriculture crops typically uses fertilizers dissolved in and delivered through the irrigation water. Selecting the appropriate fertilizer composition is important to ensure adequate and not deficient or toxic amounts of nutrients. An important consideration in selecting a fertilizer is the ratio of ammonium to nitrate- $\mathrm{N}$, because the $\mathrm{N}$ source of the fertilizer affects its potential for increasing or decreasing substrate pH (Marschner, 1995; Reed, 1996). Moreover, the N source and growing temperature interaction is important to consider (Barker and Mills, 1980). For example, under cool greenhouse conditions, the propensity for toxic ammonium- $\mathrm{N}$ to accumulate in plants is greater. This would be important 
with $O$. regnellii production in northern greenhouses, because the crop is primarily forced during the time of year in which growers often try to save energy by using as little heat as possible, which could potentially result in ammonium toxicity. Other important considerations for fertilizer selection include the fertilizer trace element charge, the content of $\mathrm{Ca}$ and $\mathrm{Mg}$, and potential acidity or basicity (Biernbaum, 1997; Reed, 1996). Careful fertilizer selection not only aids in optimal plant growth, but can also reduce production costs and nutrient runoff (Elliot, 1990; Uva et al., 1998).

With little information regarding fertilizer recommendations and irrigation practices of greenhouse production of oxalis, two experiments were designed with the following objectives: 1) to determine the effects of fertilizer concentration and irrigation method on growth of $O$. regnellii; and 2) to investigate the effect of fertilizer formulation on growth and development of $O$. regnellii and $O$. triangularis.

\section{Materials and Methods}

Expt. 1: Irrigation method and fertilization concentration. Oxalis regnellii rhizomes from a commercial Dutch supplier (Leo Berbee Bulb Co., Marysville, $\mathrm{OH})$ were used in this experiment. Five rhizomes $(\approx 2$ to $3 \mathrm{~cm})$ for each irrigation and fertilizer treatment combination were planted singly (experimental unit) in $10-\mathrm{cm}(0.5-\mathrm{L})$ standard plastic pots on $28 \mathrm{Apr}$. 2009 using a commercial peat-based media substrate (Metro Mix 360; Sun Gro Horticulture Ltd., Vancouver, Canada). Oxalis plants were grown in a greenhouse under ambient light and photoperiod conditions at $42^{\circ} \mathrm{N}$ latitude at $21{ }^{\circ} \mathrm{C} \pm 0.02$ (mean $\pm \mathrm{SE}$ ). Plants were spaced so that plant canopies would not touch, encompassing $\approx 1.5 \mathrm{ft}^{2}$ per pot. The treatments were arranged as a split plot with irrigation method as the main plot factor and fertilizer concentration as the subplot factor. The five experimental units for each fertilizer treatment were randomly arranged on each bench.

Pots were irrigated using one of two irrigation treatments: subirrigation or overhead irrigation (drip irrigation). Plants were irrigated daily, or as needed, with one of five fertilizer treatments: $50,100,200,300$, or $500 \mathrm{mg} \cdot \mathrm{L}^{-1}$ $\mathrm{N}$ from a commercial water-soluble fertilizer that contained $21 \mathrm{~N}-2.2 \mathrm{P}-16.6 \mathrm{~K}$ and micronutrients (Jack's Professional LX Water Soluble Fertilizer 21-5-20 All Purpose; J.R. Peter's Inc., Allentown, PA). Supplemental magnesium $\left(\mathrm{MgSO}_{4} \cdot 7 \mathrm{H}_{2} \mathrm{O}\right)$ to the final rate of $30 \mathrm{mg} \cdot \mathrm{L}^{-1} \mathrm{Mg}$ was added as a result of low $\mathrm{Mg}$ levels in the tap water. The municipal tap water had an electrical conductivity (EC) of $0.4 \mathrm{dS} \cdot \mathrm{m}^{-1}$ and alkalinity of $111 \mathrm{mg} \cdot \mathrm{L}^{-1}$ $\mathrm{CaCO}_{3}$. Each bench contained its own 525-L reservoir. Fertilizer solutions were mixed directly in each reservoir at the final solution concentration. These were replaced as needed (approximately every 3 weeks) when the reservoir level dropped below 100 L. Submersible pumps connected to a manually operated switch were used to deliver the water to the subirrigation trays or the drip irrigation lines. For the subirrigation treatment, trays were filled to $3 \mathrm{~cm}$, which required $\approx 5 \mathrm{~min}$. Once the pumps were turned off, it took $10 \mathrm{~min}$ for benches to drain. Pots were irrigated to effective water-holding capacity. Overhead-irrigated plants were irrigated daily by manually turning on a drip irrigation system until water just began to leach out of the bottom of containers, i.e., leaching fraction $\approx 5 \%$.
Data collected after 5 weeks included $\mathrm{pH}$ and EC, leaf fresh weight (FW) and dry weight (DW), root dry weight (RDW), plant height and diameter with diameter being calculated as the average of two perpendicular measurements, and SPAD meter readings (Minolta Chlorophyll Meter SPAD-502; Spectrum Technologies, Plainfield, IL) of five randomly selected leaves, one per experimental unit (plant), to determine chlorophyll index. All statistical analyses were conducted using JMP Version 8 (SAS Institute, Cary, NC). Two-way analysis of variance (ANOVA) tests were conducted to identify differences in the measured parameters in response to irrigation or fertilizer treatment. General linear, quadratic, or cubic regression lines were applied as appropriate based on $r^{2}$ values to determine patterns of the measured parameters in response to fertilizer concentration.

Expt. 2: Fertilizer formulation. Oxalis regnellii and $O$. triangularis rhizomes (Leo Berbee Bulb Co., Marysville, $\mathrm{OH}$ ) that were stored at $3{ }^{\circ} \mathrm{C}$ for several months were planted on 5 Feb. 2010. Eight rhizomes $(\approx 2$ to $3 \mathrm{~cm}$ ) of each species for each fertilizer treatment were individually planted in $10-\mathrm{cm}$ (0.5-L) pots using a commercial peat-based substrate $(\mathrm{pH} \approx 5.6)$ (LC1; Sun Gro Horticulture Ltd.) and grown in a greenhouse at $21^{\circ} \mathrm{C} \pm$ 0.02 (mean $\pm \mathrm{SE}$ ) with ambient light and photoperiod at $42^{\circ} \mathrm{N}$ latitude. Plants were spaced on $30-\mathrm{cm}$ centers to reduce competition effects and arranged as a completely randomized design. Plants were fertigated, overhead by hand, typically twice per week or as needed at the initial signs of wilting with one of seven fertilizer treatments (Table 1) at $250 \mathrm{mg} \cdot \mathrm{L}^{-1} \mathrm{~N}$. Osmocote ${ }^{\circledR}$ was incorporated in the media mix at the recommended rate of $5 \mathrm{~g} \cdot \mathrm{L}^{-1}(2.5 \mathrm{~g}$ per pot) and watered with clear

Table 1. Fertilizers used to evaluate growth and development of Oxalis regnellii and O. triangularis.

\begin{tabular}{|c|c|c|c|c|c|c|c|c|c|c|c|c|c|}
\hline \multirow[b]{2}{*}{ Fertilizer } & \multicolumn{9}{|c|}{ Analysis (\%) } & \multirow{2}{*}{$\begin{array}{l}\mathrm{CCE}^{\mathrm{z}} \\
(\mathrm{lbs})\end{array}$} & \multirow{2}{*}{$\begin{array}{l}\text { Acidity/ } \\
\text { basicity }\end{array}$} & \multirow{2}{*}{$\begin{array}{c}\text { Percent of total } \\
\mathrm{NO}_{3}^{--}: \mathrm{NH}_{4}^{+}:\left(\mathrm{NH}_{2}\right)_{2} \mathrm{CO}\end{array}$} & \multirow{2}{*}{$\begin{array}{c}\text { Media } \\
\mathrm{pH}^{\mathrm{w}} / \mathrm{EC}\end{array}$} \\
\hline & $(\mathrm{N}-\mathrm{P}-\mathrm{K})$ & $\mathrm{Ca}$ & $\mathrm{Mg}$ & B & $\mathrm{Fe}^{\mathrm{v}}$ & $\mathrm{Mn}$ & $\mathrm{Cu}$ & $\mathrm{Zn}$ & Mo & & & & \\
\hline $\begin{array}{l}21-5-20 \\
\text { All Purpose }\end{array}$ & $21-2.2-16.6$ & - & 0.15 & 0.0210 & 0.0105 & 0.1050 & 0.0525 & 0.0105 & 0.0525 & 407 & $\mathrm{~A}$ & 13.08: 7.92: 0.00 & $6.6 / 1.90$ \\
\hline $\begin{array}{l}\text { 20-20-20 } \\
\text { General Purpose }^{\mathrm{x}}\end{array}$ & $20-8.8-16.6$ & - & 0.05 & 0.0068 & 0.0036 & 0.0500 & 0.0250 & 0.0009 & 0.0025 & 555 & $\mathrm{~A}$ & $6.07: 3.83: 10.10$ & $5.8 / 2.10$ \\
\hline $\begin{array}{l}15-4-15 \\
\mathrm{FeED}+\mathrm{Ca}+\mathrm{Mg}^{\mathrm{y}}\end{array}$ & $15-1.8-12.5$ & 4.00 & 2.00 & 0.0068 & $0.0112 *$ & 0.1125 & 0.0563 & 0.0750 & 0.0675 & 77 & B & $12.12: 2.88: 0.00$ & $6.7 / 2.17$ \\
\hline $\begin{array}{l}15-0-15 \\
\text { Dark Weather } \\
\text { Peat-Lite }^{\mathrm{x}}\end{array}$ & $15-0-12.5$ & 10.69 & 0.00 & 0.0150 & 0.0075 & 0.0750 & 0.0375 & 0.0075 & 0.0375 & 344 & $\mathrm{~B}$ & $13.50: 1.50: 0.00$ & $6.9 / 2.18$ \\
\hline $\begin{array}{l}15-5-15 \\
+\mathrm{Ca}+\mathrm{Mg}^{\mathrm{x}}\end{array}$ & $15-2.2-12.5$ & 5.00 & 2.00 & 0.0187 & 0.0187 & 0.075 & 0.0325 & 0.0075 & 0.0325 & 131 & B & $12.00: 3.00: 0.00$ & $6.8 / 2.40$ \\
\hline $\begin{array}{l}\text { 20-3-19 } \\
\text { Petunia FeED + } \mathrm{Mg}^{\mathrm{y}}\end{array}$ & $20-1.3-15.8$ & - & 1.34 & 0.0200 & $0.0100^{*}$ & 0.2000 & 0.0500 & 0.0100 & 0.5000 & 420 & $\mathrm{~A}$ & 11.96: 8.04: 0.00 & $6.6 / 2.01$ \\
\hline $\begin{array}{l}\text { 14-14-14 } \\
\text { Osmocote } \\
\end{array}$ & $14-4.2-11.6$ & - & - & - & - & - & - & - & - & - & - & 5.80: 8.20: 0.00 & $4.7 / 3.80$ \\
\hline
\end{tabular}

${ }^{\mathrm{z}}$ Calcium carbonate equivalent (per ton).

yProducts of Jr. Peters, Inc., Allentown, PA.

xProducts of Scotts Company, LLC.; Marysville, OH. No micronutrients supplied.

${ }^{\text {w}}$ Values were obtained at the end of the experiment. $\mathrm{pH}$ values determined using the pour-through method. $\mathrm{pH}$ and $\mathrm{EC}$ values for the two species, $O$. regnellii (n $=$

$5)$ and $O$. triangularis $(\mathrm{n}=4)$, were not significantly different; thus, data were pooled $(\mathrm{n}=9)$.

'Iron source was supplied as Fe-EDTA, except those marked with an asterisk, which also included Fe-DTPA and Fe-EDDHA sources.

$\mathrm{Ca}=$ calcium; $\mathrm{Mg}=$ magnesium; $\mathrm{B}=$ boron; $\mathrm{Fe}=$ iron; $\mathrm{Mn}=$ manganese; $\mathrm{Cu}=$ copper; $\mathrm{Zn}=$ zinc; $\mathrm{Mo}=$ molybdenum; EC = electrical conductivity. 
water for each irrigation. The fertilizers chosen are typical greenhouse formulations representing a range of different nitrate: ammonium:urea ratios, varying potential acidity/basicity, nutrient ratios, and Fe form(s) supplied. Some fertilizers provided additional macro- and/or micronutrients such as $\mathrm{Fe}, \mathrm{Ca}$, and $\mathrm{Mg}$ to enhance plant growth in a greenhouse situation (Table 1).

After 10 weeks, plant height and width (calculated as described previously), FWs and DWs, SPAD meter readings (as described previously), and $\mathrm{pH}$ and $\mathrm{EC}$ readings $(\mathrm{n}=9)$ were obtained. $\mathrm{pH}$ and $\mathrm{EC}$ values for the two species, O. regnellii $(\mathrm{n}=5)$ and $O$. triangularis $(\mathrm{n}=4)$, were not significantly different; thus, data were pooled (Table 2). Leaf chlorosis ratings were taken. Ratings were determined using a rating scale from 0 to 5: $0=$ no chlorosis; 1 = minimal chlorosis, slight yellowing; 2 = general leaf yellowing; $3=$ progressed leaf yellowing with initial stages of green veins; $4=$ distinct interveinal chlorosis; and $5=$ severe chlorosis, often exhibiting bleaching. Dried leaf tissue samples were analyzed at a commercial laboratory to determine tissue nutrient concentrations. For each individual species, one-way ANOVA tests were conducted to identify differences in the measured parameters in response to fertilizer formulation and Tukey's honestly significant difference method was used to conduct pairwise comparisons.

\section{Results and Discussion}

Expt. 1: Irrigation method and fertilization concentration. The main effects of fertilizer concentration and irrigation type were significant for all growth parameters (Table 3 ). The only significant interaction of fertilizer and irrigation was for shoot FW. For overhead irrigation, the greatest $\mathrm{FW}$ occurred between $50 \mathrm{mg} \cdot \mathrm{L}^{-1} \mathrm{~N}$ and $300 \mathrm{mg} \cdot \mathrm{L}^{-1} \mathrm{~N}$, whereas no optimal fertility for FW was observed between treatments for subirrigated plants. Fresh weight in overhead-irrigated plants was significantly decreased at $500 \mathrm{mg} \cdot \mathrm{L}^{-1} \mathrm{com}$ pared with all other fertilization concentrations (Fig. 1A). Overhead-irrigated plants had greater DW compared with subirrigated plants. Significantly increased DWs occurred at $100 \mathrm{mg} \cdot \mathrm{L}^{-1}$ compared with $500 \mathrm{mg} \cdot \mathrm{L}^{-1}$ for both irrigation methods (Fig. 1B). Frett et al. (1985) observed significant reduction of petunia shoot DW with higher $\mathrm{N}$ concentrations $\left(400 \mathrm{mg} \cdot \mathrm{L}^{-1}\right)$. In both irrigation systems, a cubic response was observed for RDW, for which we do not have a clear explanation. Overhead irrigation and subirrigation rates of $200 \mathrm{mg} \cdot \mathrm{L}^{-1}$ and $100 \mathrm{mg} \cdot \mathrm{L}^{-1}$ significantly reduced RDW compared with 50 and $300 \mathrm{mg} \cdot \mathrm{L}^{-1}$ treatments. In both irrigation methods, $500 \mathrm{mg} \cdot \mathrm{L}^{-1}$ reduced root RDW by $75 \%$ as compared with $300 \mathrm{mg} \cdot \mathrm{L}^{-1}$ (Fig. 1C).

A negative linear relationship occurred between plant height and $\mathrm{N}$ concentration in both irrigation practices, although height was only significantly decreased at the $500 \mathrm{mg} \cdot \mathrm{L}^{-1}$ level for overhead irrigation compared with the 50 and $100 \mathrm{mg} \cdot \mathrm{L}^{-1}$ rates (Fig. 2A). Using subirrigation, Poole and Conover (1992) found increasing fertilizer rates did not significantly increase or decrease plant height in three different foliage plants. Similar results were

Table 2. $\mathrm{pH}$ and electroconductivity (EC) means $( \pm \mathrm{SE})$ of Oxalis regnellii plants grown using either overhead or subirrigation at different fertilizer concentrations after 5 weeks.

\begin{tabular}{lcrr}
\hline Irrigation method & $\begin{array}{c}\text { Fertilizer concn } \\
\left(\mathrm{mg} \cdot \mathrm{L}^{-1} \mathrm{~N}\right)\end{array}$ & $\mathrm{pH}$ & $\mathrm{EC}\left(\mathrm{dS} \cdot \mathrm{m}^{-1}\right)$ \\
\hline Overhead & 50 & $7.26(0.22)$ & $1.30(0.19)$ \\
& 100 & $6.67(0.22)$ & $1.55(0.19)$ \\
& 200 & $5.12(0.22)$ & $1.09(0.19)$ \\
& 300 & $4.99(0.22)$ & $4.89(0.25)$ \\
Subirrigation & 500 & $4.90(0.22)$ & $3.36(0.21)$ \\
& & & $1.85(0.34)$ \\
& 50 & $7.38(0.22)$ & $2.67(0.38)$ \\
& 100 & $6.26(0.25)$ & $7.32(0.34)$ \\
& 200 & $4.93(0.22)$ & $9.46(0.34)$ \\
& 300 & $5.24(0.22)$ & $13.23(0.34)$ \\
\hline
\end{tabular}

Table 3. Two-way analysis of variance for the effect of irrigation type (Irr; overhead and subirrigation), fertilizer concentration Conc; 50, 100, 200, 300, and $500 \mathrm{mg} \cdot \mathrm{L}^{-1} \mathrm{~N}$; and the interaction (Irr $\times$ Conc) on Oxalis regnellii growth parameters.

\begin{tabular}{|c|c|c|c|c|c|c|c|c|c|}
\hline $\begin{array}{l}\text { Main effects and } \\
\text { interactions }\end{array}$ & $\mathrm{df}$ & MSE & $P$ value & $\mathrm{df}$ & MSE & $P$ & $\mathrm{df}$ & MSE & $P$ \\
\hline Source & \multicolumn{3}{|c|}{ Shoot FW } & \multicolumn{3}{|c|}{ Shoot DW } & \multicolumn{3}{|c|}{ Root $D W$} \\
\hline Irr & 1 & 3,412 & $<0.0001$ & 1 & 16 & 0.0008 & 1 & 0.32 & $<0.0001$ \\
\hline Conc & 4 & 164,485 & $<0.0001$ & 4 & 43 & 0.0362 & 4 & 0.27 & 0.0027 \\
\hline \multirow[t]{2}{*}{ Irr $\times$ Conc } & 4 & 1,238 & 0.0148 & 4 & 1 & 0.6460 & 4 & 0.04 & 0.2466 \\
\hline & \multicolumn{3}{|c|}{$S P A D$} & \multicolumn{3}{|c|}{ Height } & \multicolumn{3}{|c|}{ Diameter } \\
\hline Irr & 1 & 220 & $<0.0001$ & 1 & 34 & 0.0003 & 1 & 103 & 0.0003 \\
\hline Conc & 4 & 176 & 0.0028 & 4 & 34 & 0.0134 & 4 & 238 & 0.0006 \\
\hline Irr $\times$ Conc & 4 & 41 & 0.0696 & 4 & 7 & 0.2269 & 4 & 20 & 0.3197 \\
\hline
\end{tabular}

$\mathrm{MSE}=$ mean square error; $\mathrm{FW}=$ fresh weight; $\mathrm{DW}=$ dry weight.
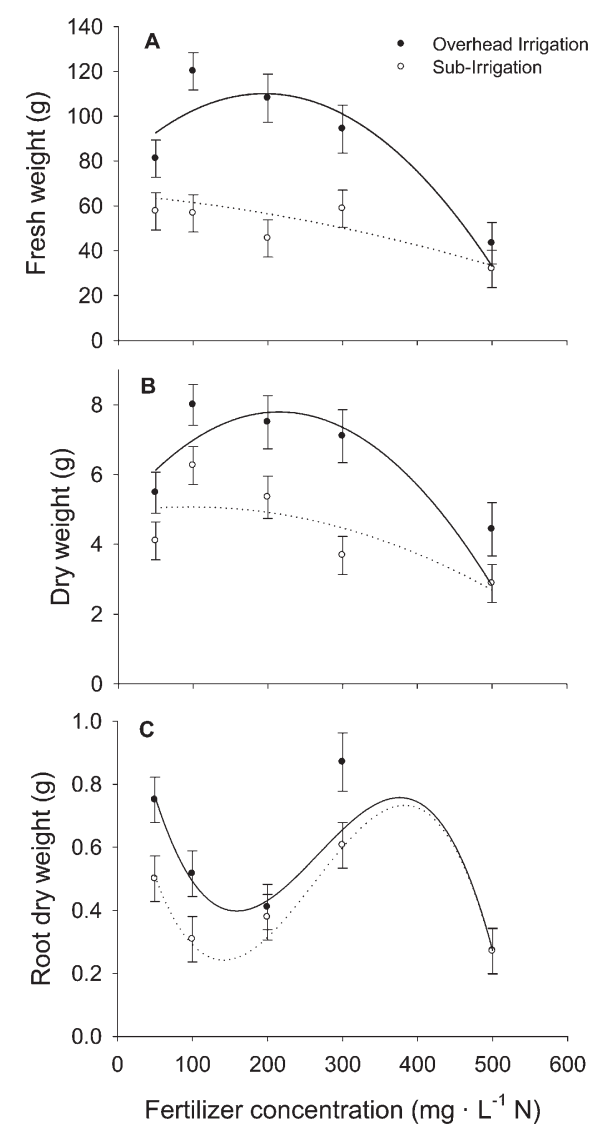

Fig. 1. Effects of irrigation type (overhead and subirrigation) and fertilizer concentration effects on growth parameters of Oxalis regnellii. The regression equations, associated $P$ values for the associated $\mathrm{F}$ statistic, and $r^{2}$ values are as follows: (A) fresh weight: overhead; $\mathrm{y}=-8.28$ $\mathrm{e}^{-4 *(\mathrm{x}-223.91)^{2}-(0.05 * \mathrm{x})+120.04(P=0.0021)}$ $\left(r^{2}=0.46\right)$; subirrigation; $\mathrm{y}=-6.78 \mathrm{e}^{-5 *}(\mathrm{x}-243.48)^{2}-$ $0.06 * \mathrm{x}+69.09(P=0.0060)\left(r^{2}=0.40\right) ;(\mathbf{B})$ dry weight: overhead; $\mathrm{y}=-6.13 \mathrm{e}^{-5 *}(\mathrm{x}-223.91)^{2}-$ $0.001 * \mathrm{x}+8.04(P=0.0045)\left(r^{2}=0.41\right)$; subirrigation; $\mathrm{y}=-1.4686 \mathrm{e}^{-5 *}(\mathrm{x}-231.25)^{2}-(0.004 * \mathrm{x})+$ $5.72(P=0.0133)\left(r^{2}=0.34\right) ;(\mathbf{C})$ root dry weight: overhead; $\mathrm{y}=-7.03 \mathrm{e}^{-8 *}(\mathrm{x}-227.08)^{3}+$ $8.55 \mathrm{e}^{-6 *}(\mathrm{x}-227.08)^{2}+0.002 * \mathrm{x}-0.01(P=0.0194)$ $\left(r^{2}=0.38\right)$; subirrigation; $\mathrm{y}=-7.01 \mathrm{e}-{ }^{8 *}(\mathrm{x}-$ $231.25)^{3}+6.49 \mathrm{e}^{-6 *}(\mathrm{x}-231.25)^{2}+0.003 * \mathrm{x}-0.27$ $(P<0.0001)\left(r^{2}=0.68\right)$.

observed for both irrigation methods in relation to plant diameter. The smallest plants were observed at $500 \mathrm{mg} \cdot \mathrm{L}^{-1}$ (Fig. 2B) compared with 100 and $50 \mathrm{mg} \cdot \mathrm{L}^{-1}$ for overhead and subirrigated plants, respectively.

The greenest plants, or those with the highest SPAD readings, for overhead irrigation were observed at $300 \mathrm{mg} \cdot \mathrm{L}^{-1}$ and were significantly less green at 50 and $100 \mathrm{mg} \cdot \mathrm{L}^{-1}$. In subirrigated plants, SPAD readings increased linearly with increasing $\mathrm{N}$ concentration (Fig. 2C). Greener plants were observed at the highest $\mathrm{N}$ rates (300 and $500 \mathrm{mg} \cdot \mathrm{L}^{-1}$ ) when compared with the lowest fertilizer rate. Kang and van Iersel (2002) observed chlorophyll content in celosia, dianthus, gomphrena, stock, and zinnia increased as fertilizer solutions increased up to $420 \mathrm{mg} \cdot \mathrm{L}^{-1}$. 

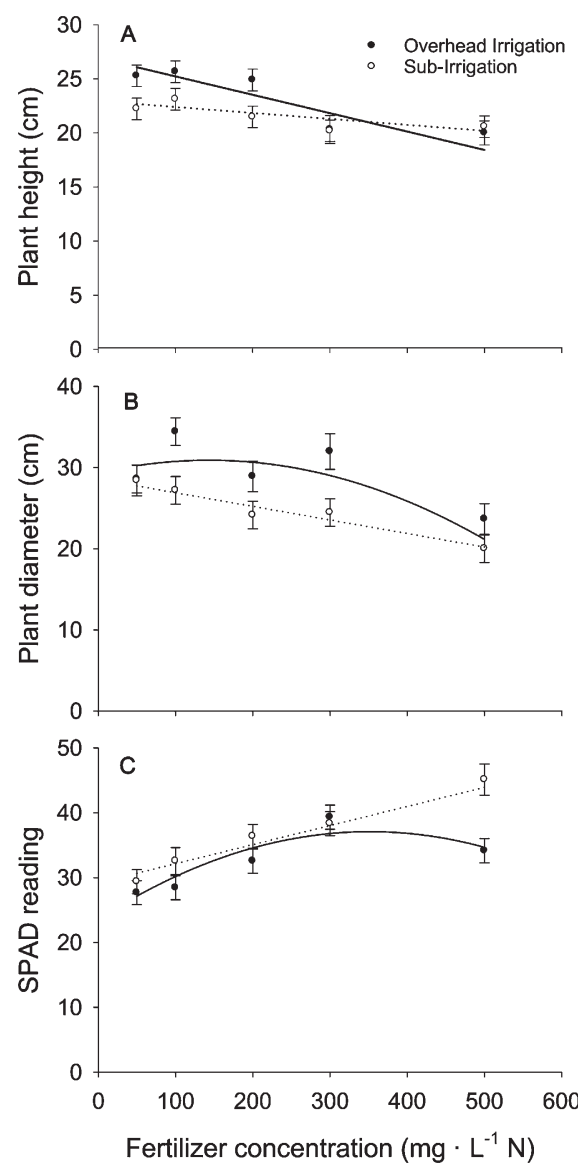

Fig. 2. Effects of irrigation type (overhead and subirrigation) and fertilizer concentration effects on growth parameters of Oxalis regnellii. SPAD readings (units) are averages of five readings obtained at destructive harvest per replication. The regression equations, associated $P$ values for the associated $\mathrm{F}$ statistic, and $r^{2}$ values are as follows: (A) plant height: overhead; $\mathrm{y}=-0.02 *(\mathrm{x})+26.92$ $(P=0.0004)\left(r^{2}=0.43\right)$; subirrigation; $\mathrm{y}=$ $-0.0056^{*}(\mathrm{x})+22.94(P=0.0346)\left(r^{2}=0.19\right)$; (B) plant diameter: overhead; $\mathrm{y}=-7.66 \mathrm{e}^{-5 *}(\mathrm{x}-$ $223.91)^{2}-0.012 \mathrm{x}+33.16(P=0.0100)\left(r^{2}=\right.$ $0.37)$; subirrigation; $\mathrm{y}=-0.017 \mathrm{x}+28.55(P=$ $0.0021)\left(r^{2}=0.34\right)$; (C) SPAD reading: overhead; $\mathrm{y}=-1.091 \mathrm{e}^{-4 *}(\mathrm{x}-237.50)^{2}+0.025 * \mathrm{x}+29.73(P$ $=0.0060)\left(r^{2}=0.39\right)$; subirrigation; $\mathrm{y}=0.029 *(\mathrm{x})$ $+29.19(P<0.0001)\left(r^{2}=0.66\right)$.

In the present study, overhead irrigation produced higher quality plants in terms of overall plant stature and increased root mass for $O$. regnellii. High $\mathrm{N}$ fertilizer rates, above $300 \mathrm{mg} \cdot \mathrm{L}^{-1} \mathrm{~N}$ and rates lower than 100 $\mathrm{mg} \cdot \mathrm{L}^{-1} \mathrm{~N}$, should be avoided, because growth of $O$. regnellii is negatively affected. Similar to Dole et al. (1994), Kent and Reed (1996), and Yelanich and Biernbaum (1993), optimal fertilization concentrations are slightly lower for subirrigation methods compared with overhead irrigation, because soluble salt accumulation increased with increasing fertilizer rates (Table 2), which could likely be attributed to less water-leaching events. Generally, whiter, brighter root systems were observed in the overhead-irrigated plants as compared with subirrigated plants and for plants with fertilizer treatments of 200 and 300 L N (personal observation).
Expt. 2: Fertilizer formulation. Fertilizer type had significant effects on the measured growth parameters of $O$. regnellii and $O$. triangularis (Table 4). Oxalis regnellii plants fertilized with $15 \mathrm{~N}-2.2 \mathrm{P}-12.5 \mathrm{~K}$ had significantly higher FW, DW, were taller, and produced wider plants than plants fertilized with $20 \mathrm{~N}-8.8 \mathrm{P}-16.6 \mathrm{~K}$ and $15 \mathrm{~N}-0 \mathrm{P}-12.5 \mathrm{~K}$ compositions. The greenest $O$. regnellii plants, those with the highest SPAD readings, were produced with $14 \mathrm{~N}-4.2 \mathrm{P}-11.6 \mathrm{~K}$ treatments but were just as green as plants fertilized with $20 \mathrm{~N}-1.3 \mathrm{P}-15.8 \mathrm{~K}$. The least chlorotic plants (lowest chlorosis rating) were those fertilized with $20 \mathrm{~N}-1.3 \mathrm{P}-15.8 \mathrm{~K}$ containing three different $\mathrm{Fe}$ chelate forms, which correlated with the highest leaf tissue Fe concentrations (Table 5). Greatest chlorosis incidence (although only significantly more than fertilizer treatments of $20 \mathrm{~N}-1.3 \mathrm{P}-15.8 \mathrm{~K}$ and $14 \mathrm{~N}-$ $4.2 \mathrm{P}-11.6 \mathrm{~K}$ ) and lower leaf tissue Fe concentrations were observed in plants treated with $15 \mathrm{~N}-0 \mathrm{P}-12.5 \mathrm{~K}$ with Fe supplied only in the EDTA form.

Oxalis triangularis plant FW increased 2.5 and 1.7 times when fertilized with $20 \mathrm{~N}-$ $1.3 \mathrm{P}-15.8 \mathrm{~K}$ compared with those treated with $15 \mathrm{~N}-0 \mathrm{P}-12.5 \mathrm{~K}$ and $14 \mathrm{~N}-4.2 \mathrm{P}-11.6 \mathrm{~K}$, respectively. Plant DW decreased significantly by half between plants fertilized with $15 \mathrm{~N}-0 \mathrm{P}-12.5 \mathrm{~K}$ as compared with the $20 \mathrm{~N}-$ $1.3 \mathrm{P}-15.8 \mathrm{~K}$ formulation. Similarly, plant height and width decreased significantly between those fertilizer formulations. SPAD readings were recorded despite $O$. triangularis' purple leaf appearance and little differences were found between "greenness" levels.

Tissue nutrient analysis indicated that for most fertilizers and tissue concentrations for $\mathrm{N}$, potassium $(\mathrm{K}), \mathrm{Mg}$, boron, and copper were in the sufficient range (per commercial laboratory guidelines) for both species (Table 5). Phosphorus tissue levels were acceptable for all fertilizer treatments except for the fertilizer formulation with no $\mathrm{P}$ added $(15 \mathrm{~N}-0 \mathrm{P}-12.5 \mathrm{~K})$, in which $\mathrm{P}$ levels were deficient in $O$. regnellii. In both species, final plant height was significantly shorter for P-free fertilizer treatments. Phosphorus deficiency is known to reduce plant height (Hansen and Nielsen, 2001; Nelson et al., 2002; Rideout and Overstreet, 2003).

Calcium levels were on the low side of the recommendation levels for sufficient plant growth, even with fertilizer formulations providing extra $\mathrm{Ca}$. Iron levels varied between different fertilizer treatments, as expected. Both $20 \mathrm{~N}-1.3 \mathrm{P}-15.8 \mathrm{~K}$ and $15 \mathrm{~N}-$ $1.8 \mathrm{P}-12.5 \mathrm{~K}$ fertilizer formulations contain three Fe chelates (Fe EDTA, Fe DTPA, and Fe EDDHA) (Table 1) to increase Fe availability in the case of elevated $\mathrm{pH}$ levels. One might expect higher leaf tissue Fe concentrations when fertilizing with the aforementioned fertilizers. Plants fertilized with $20 \mathrm{~N}-1.3 \mathrm{P}-15.8 \mathrm{~K}$ had the highest leaf tissue Fe concentrations $\left(85.0 \mathrm{mg} \cdot \mathrm{kg}^{-1}\right)$ and lower $\mathrm{Ca}$ concentrations, whereas plants fertilized with $15 \mathrm{~N}-1.8 \mathrm{P}-12.5 \mathrm{~K}$ had significantly lower leaf tissue Fe concentrations $\left(60.2 \mathrm{mg} \cdot \mathrm{kg}^{-1}\right)$ and higher $\mathrm{Ca}$ concentrations. The reduced $\mathrm{Fe}$ concentration in these tissues despite having several Fe sources available for plant uptake could be the result of an interaction between $\mathrm{Fe}$ and additional $\mathrm{Ca}$ provided in the $15 \mathrm{~N}-1.8 \mathrm{P}-12.5 \mathrm{~K}$ formulation. Manganese (Mn) levels for several fertilizer treatments in O. regnellii had Mn levels near the lower sufficiency concentration but should not be of concern. In a previous experiment (manuscript in progress) we found that hydroponically grown oxalis plants grown in Mn-free solutions showed no Mn-deficient symptoms at $27 \mathrm{mg} \cdot \mathrm{kg}^{-1}$. This could possibly be explained by a low minimum Mn requirement for oxalis or initial Mn levels in rhizome tissue were sufficient. Molybdenum (Mo)

Table 4. Fertilizer effects on growth and development of Oxalis regnellii and O. triangularis. ${ }^{\mathrm{z}}$

\begin{tabular}{lllllll}
\hline $\begin{array}{l}\text { Fertilizer analysis } \\
(\mathrm{N}-\mathrm{P}-\mathrm{K})\end{array}$ & $\begin{array}{c}\text { Fresh wt } \\
(\mathrm{g})\end{array}$ & $\begin{array}{c}\text { Dry wt } \\
(\mathrm{g})\end{array}$ & $\mathrm{Ht}(\mathrm{cm})$ & $\begin{array}{c}\text { Width } \\
(\mathrm{cm})\end{array}$ & $\begin{array}{c}\text { SPAD } \\
(\text { units })\end{array}$ & $\begin{array}{c}\text { Chlorosis } \\
\text { rating }^{\mathrm{x}}\end{array}$ \\
\hline & & \multicolumn{7}{c}{ O. regnellii } \\
$21-2.2-16.6$ & $36.5 \mathrm{ab}^{\mathrm{y}}$ & $2.58 \mathrm{ab}$ & $13.3 \mathrm{ab}$ & $21.7 \mathrm{ab}$ & $29.1 \mathrm{~cd}$ & $1.20 \mathrm{ab}$ \\
$20-8.8-16.6$ & $28.0 \mathrm{bc}$ & $1.94 \mathrm{~b}$ & $11.4 \mathrm{bc}$ & $20.3 \mathrm{~b}$ & $31.4 \mathrm{bc}$ & $1.13 \mathrm{ab}$ \\
$15-1.8-12.5$ & $31.3 \mathrm{abc}$ & $2.24 \mathrm{ab}$ & $13.8 \mathrm{ab}$ & $21.8 \mathrm{ab}$ & $28.5 \mathrm{~cd}$ & $1.63 \mathrm{a}$ \\
$15-0-12.5$ & $18.8 \mathrm{c}$ & $1.78 \mathrm{~b}$ & $9.38 \mathrm{c}$ & $21.7 \mathrm{ab}$ & $27.5 \mathrm{~d}$ & $1.88 \mathrm{a}$ \\
$15-2.2-12.5$ & $45.5 \mathrm{a}$ & $3.24 \mathrm{a}$ & $14.6 \mathrm{a}$ & $24.6 \mathrm{a}$ & $29.6 \mathrm{~cd}$ & $1.00 \mathrm{abc}$ \\
$20-1.3-15.8$ & $34.4 \mathrm{abc}$ & $2.50 \mathrm{ab}$ & $13.1 \mathrm{ab}$ & $24.0 \mathrm{ab}$ & $33.9 \mathrm{ab}$ & $0.08 \mathrm{c}$ \\
$14-4.2-11.6$ & $28.3 \mathrm{bc}$ & $2.39 \mathrm{ab}$ & $13.3 \mathrm{ab}$ & $23.7 \mathrm{ab}$ & $35.8 \mathrm{a}$ & $0.50 \mathrm{bc}$
\end{tabular}

$\left(\right.$ Osmocote $\left.{ }^{\circledR}\right)$
20-8.8-16.6

15-1.8-12.5

15-0-12.5

15-2.2-12.5

20-1.3-15.8

14-4.2-11.6

(Osmocote $^{\circledR}$ )

\section{1-2.2-16.6}

$\begin{array}{llrll}23.1 \mathrm{abc} & 1.67 \mathrm{ab} & 12.7 \mathrm{a} & 19.2 \mathrm{ab} & 34.5 \mathrm{ab} \\ 26.6 \mathrm{ab} & 1.81 \mathrm{ab} & 13.9 \mathrm{a} & 20.1 \mathrm{a} & 34.4 \mathrm{ab} \\ 22.0 \mathrm{abc} & 1.68 \mathrm{ab} & 14.1 \mathrm{a} & 20.7 \mathrm{a} & 33.1 \mathrm{~b} \\ 12.2 \mathrm{c} & 1.03 \mathrm{~b} & 7.9 \mathrm{~b} & 16.0 \mathrm{~b} & 35.4 \mathrm{ab} \\ 21.0 \mathrm{abc} & 1.49 \mathrm{ab} & 12.4 \mathrm{a} & 19.7 \mathrm{ab} & 35.8 \mathrm{ab} \\ 30.6 \mathrm{a} & 2.14 \mathrm{a} & 13.7 \mathrm{a} & 20.8 \mathrm{a} & 36.1 \mathrm{ab} \\ 18.5 \mathrm{bc} & 1.38 \mathrm{ab} & 13.5 \mathrm{a} & 17.9 \mathrm{ab} & 38.5 \mathrm{a}\end{array}$

zPlants were fertilized with $250 \mathrm{mg} \cdot \mathrm{L}^{-1} \mathrm{~N}$ of a water-soluble fertilizer with each watering or with the slowrelease fertilizer Osmocote $\AA$. Osmocote ${ }^{\circledR}$ was incorporated into media at the rate of $2.5 \mathrm{~g}$ per 10 -cm pot. 'Letters after values in each column for each species represent mean separation using Tukey's honestly significant difference at $P=0.05$.

${ }^{\mathrm{x}}$ leaf chlorosis ratings that were determined from a rating scale from 0 to $5: 0=$ no chlorosis; $1=$ minimal chlorosis, slight yellowing; 2 = general leaf yellowing; 3 = progressed leaf yellowing with initial stages of green veins; 4 = distinct interveinal chlorosis; 5 = severe chlorosis, often exhibiting bleaching. 
Table 5. Fertilizer effects on leaf tissue nutrient concentrations after 10 weeks in Oxalis regnellii and O. triangularis.

\begin{tabular}{|c|c|c|c|c|c|c|c|c|c|c|c|}
\hline \multirow{2}{*}{$\begin{array}{l}\text { Fertilizer analysis } \\
(\mathrm{N}-\mathrm{P}-\mathrm{K})\end{array}$} & \multicolumn{5}{|c|}{ Percent } & \multicolumn{6}{|c|}{$\left(\mathrm{mg} \cdot \mathrm{kg}^{-1}\right)$} \\
\hline & $\mathrm{N}$ & $\mathrm{P}$ & $\mathrm{K}$ & $\mathrm{Ca}$ & $\mathrm{Mg}$ & B & $\mathrm{Fe}$ & $\mathrm{Mn}$ & $\mathrm{Cu}$ & $\mathrm{Zn}$ & Mo \\
\hline Normal range $^{z}$ & $3.50-5.50$ & $0.35-1.00$ & $2.00-8.00$ & $0.80-3.00$ & $0.20-1.50$ & $30.0-150.0$ & $60.0-200.0$ & $50.0-200.0$ & $5.00-25.0$ & $30.0-150.0$ & $0.50-5.00$ \\
\hline \multicolumn{12}{|c|}{ O. regnellii } \\
\hline $21-2.2-16.6$ & $4.35 \mathrm{a}^{\mathrm{y}}$ & $0.44 \mathrm{ab}$ & $4.28 \mathrm{a}$ & $0.85 \mathrm{bc}$ & $0.63 \mathrm{~b}$ & $54.8 \mathrm{ab}$ & $65.5 \mathrm{bcd}$ & $57.8 \mathrm{c}$ & $13.3 \mathrm{ab}$ & $28.5 \mathrm{ab}$ & $7.9 \mathrm{~b}$ \\
\hline $20-8.8-16.6$ & $4.16 \mathrm{a}$ & $0.43 \mathrm{ab}$ & $3.98 \mathrm{ab}$ & $0.81 \mathrm{c}$ & $0.66 \mathrm{ab}$ & $39.4 \mathrm{c}$ & $74.1 \mathrm{ab}$ & $63.6 \mathrm{bc}$ & $8.9 \mathrm{~cd}$ & $22.7 \mathrm{~b}$ & $3.6 \mathrm{~cd}$ \\
\hline $15-1.8-12.5$ & $4.21 \mathrm{a}$ & $0.46 \mathrm{a}$ & $3.81 \mathrm{bc}$ & $1.00 \mathrm{a}$ & $0.73 \mathrm{a}$ & $36.0 \mathrm{c}$ & $60.2 \mathrm{de}$ & $82.0 \mathrm{ab}$ & $8.9 \mathrm{~cd}$ & $28.7 \mathrm{ab}$ & $8.7 \mathrm{ab}$ \\
\hline $15-0-12.5$ & $3.52 \mathrm{~b}$ & $0.10 \mathrm{~d}$ & $2.88 \mathrm{~d}$ & $0.80 \mathrm{c}$ & $0.50 \mathrm{c}$ & $48.5 \mathrm{~b}$ & $49.5 \mathrm{e}$ & $67.0 \mathrm{bc}$ & $10.4 \mathrm{bc}$ & $27.7 \mathrm{ab}$ & $7.3 \mathrm{~b}$ \\
\hline $15-2.2-12.5$ & $4.04 \mathrm{a}$ & $0.44 \mathrm{ab}$ & $3.96 \mathrm{~b}$ & $0.94 \mathrm{ab}$ & $0.64 \mathrm{ab}$ & $54.3 \mathrm{~b}$ & $62.7 \mathrm{~cd}$ & $97.5 \mathrm{a}$ & $15.8 \mathrm{a}$ & $32.5 \mathrm{a}$ & $11.6 \mathrm{a}$ \\
\hline $20-1.3-15.7$ & $4.05 \mathrm{ab}$ & $0.27 \mathrm{c}$ & $3.93 \mathrm{~b}$ & $0.88 \mathrm{abc}$ & $0.65 \mathrm{ab}$ & $57.6 \mathrm{ab}$ & $85.0 \mathrm{a}$ & $64.0 \mathrm{bc}$ & $12.7 \mathrm{ab}$ & $27.3 \mathrm{ab}$ & $6.3 \mathrm{bc}$ \\
\hline $\begin{array}{l}\text { 14-4.2-11.6 } \\
\quad\left(\text { Osmocote }{ }^{\circledR}\right)\end{array}$ & $4.11 \mathrm{a}$ & $0.40 \mathrm{~b}$ & $3.57 \mathrm{c}$ & $0.75 \mathrm{c}$ & $0.66 \mathrm{ab}$ & $63.6 \mathrm{a}$ & $72.1 \mathrm{bc}$ & $55.2 \mathrm{c}$ & $7.04 \mathrm{~d}$ & $27.7 \mathrm{ab}$ & $1.8 \mathrm{~d}$ \\
\hline \multicolumn{12}{|c|}{ O. triangularis } \\
\hline $21-2.2-16.6$ & $4.13 \mathrm{a}$ & $0.41 \mathrm{a}$ & $3.54 \mathrm{a}$ & $0.86 \mathrm{ab}$ & $0.71 \mathrm{bc}$ & $71.5 \mathrm{abc}$ & $70.6 \mathrm{bc}$ & $70.7 \mathrm{c}$ & $10.3 \mathrm{bc}$ & $42.7 \mathrm{bc}$ & $11.9 \mathrm{~b}$ \\
\hline $20-8.8-16.6$ & $3.94 \mathrm{ab}$ & $0.42 \mathrm{a}$ & $3.53 \mathrm{a}$ & $0.83 \mathrm{~b}$ & $0.71 \mathrm{bc}$ & $61.4 \mathrm{bc}$ & $78.7 \mathrm{ab}$ & $84.1 \mathrm{abc}$ & $8.4 \mathrm{~d}$ & $34.6 \mathrm{de}$ & $5.1 \mathrm{c}$ \\
\hline $15-1.8-12.5$ & $3.65 \mathrm{bc}$ & $0.39 \mathrm{a}$ & $3.15 \mathrm{~b}$ & $0.92 \mathrm{ab}$ & $0.80 \mathrm{a}$ & $56.0 \mathrm{c}$ & $54.2 \mathrm{~d}$ & $95.9 \mathrm{ab}$ & $9.5 \mathrm{~cd}$ & $34.5 \mathrm{de}$ & $11.8 \mathrm{~b}$ \\
\hline $15-0-12.5$ & $3.61 \mathrm{c}$ & $0.26 \mathrm{~b}$ & $3.18 \mathrm{~b}$ & $0.90 \mathrm{ab}$ & $0.68 \mathrm{c}$ & $83.4 \mathrm{a}$ & $67.0 \mathrm{c}$ & $97.1 \mathrm{ab}$ & $11.9 \mathrm{~b}$ & $46.2 \mathrm{ab}$ & $20.8 \mathrm{a}$ \\
\hline $15-2.2-12.5$ & $4.25 \mathrm{a}$ & $0.43 \mathrm{a}$ & $3.58 \mathrm{a}$ & $0.95 \mathrm{a}$ & $0.74 \mathrm{abc}$ & $78.9 \mathrm{a}$ & $78.3 \mathrm{ab}$ & $101.8 \mathrm{a}$ & $15.7 \mathrm{a}$ & $49.8 \mathrm{a}$ & $18.3 \mathrm{a}$ \\
\hline $20-1.3-15.7$ & $3.98 \mathrm{ab}$ & $0.37 \mathrm{a}$ & $3.45 \mathrm{ab}$ & $0.82 \mathrm{~b}$ & $0.69 \mathrm{bc}$ & $73.5 \mathrm{ab}$ & $80.3 \mathrm{ab}$ & $71.0 \mathrm{c}$ & $8.9 \mathrm{~cd}$ & $38.2 \mathrm{~cd}$ & $11.3 \mathrm{~b}$ \\
\hline $\begin{array}{l}14-4.2-11.6 \\
(\text { Osmocote }\end{array}$ & $3.98 \mathrm{ab}$ & $0.40 \mathrm{a}$ & $3.30 \mathrm{ab}$ & $0.83 \mathrm{~b}$ & $0.77 \mathrm{ab}$ & $67.8 \mathrm{abc}$ & $88.8 \mathrm{a}$ & $73.9 \mathrm{bc}$ & $8.3 \mathrm{~d}$ & $31.0 \mathrm{e}$ & $2.8 \mathrm{c}$ \\
\hline
\end{tabular}

${ }^{\mathrm{z}}$ Normal range based on laboratory recommendations.

${ }^{y}$ Letters after values in each column for each species represent mean separation using Tukey's honestly significant difference at $P=0.05$.

$\mathrm{N}=$ nitrogen; $\mathrm{P}=$ phosphorus; $\mathrm{K}=$ potassium; $\mathrm{Ca}=$ calcium; $\mathrm{Mg}=$ magnesium; $\mathrm{B}=$ boron; $\mathrm{Fe}=$ iron; $\mathrm{Mn}=\mathrm{manganese} ; \mathrm{Cu}=\mathrm{copper} ; \mathrm{Zn}=\mathrm{zinc} ; \mathrm{Mo}=\mathrm{molybdenum}$.

concentrations were significantly higher than the upper sufficiency range, especially for $O$. triangularis. Little information is known for Mo concentration requirements for many plants and Mo toxicities in greenhouse production are not common. In $O$. regnellii, zinc levels were marginally deficient for all fertilizer formulations, with the exception of the $15 \mathrm{~N}-2.2 \mathrm{P}-12.5 \mathrm{~K}$ treatment; however, no deficiency symptoms were observed. Zinc deficiencies are uncommon in greenhouse crops (Reed, 1996).

A well-developed, efficient fertilization program requires well-timed and adequate nutrition levels throughout crop production and provides sufficient post-production nutrition in the retail environment for consumers. The controlled-release fertilizer (CRF) (i.e., Osmocote $\left.{ }^{\circledR}, 14 \mathrm{~N}-4.2 \mathrm{P}-11.6 \mathrm{~K}\right)$ formulation produced marketable plants in our study (although not the largest plants). Oxalis has a short-term production schedule in which CRFs may work well, especially with preplant incorporation, which could reduce labor and potential water-soluble fertilizer costs during greenhouse production. Moreover, an added benefit to CRF is greater control over nutrient leaching during greenhouse production based on the interaction of the physical properties of the prill, greenhouse or media temperature, and water application frequency and method (Cabrera, 1997; Haver and Schuch, 1996; Klock-Moore and Broschat, 1999; LeaCox, et al., 2001; Medina et al., 2008). Further investigations of CRF application rates and formulations with Oxalis forcing are warranted.

Irrigation method, fertilizer concentration, and fertilizer formulation are not the only factors that affect crop production. Other factors include, but are not limited to, temperature (Kang and van Iersel, 2001), light intensity (Masson et al., 1991), growing medium (James and van Iersel, 2001; Poole and Conover, 1992), and specific nutrient proportions (Haley and Reed, 2004). These other factors should be considered when selecting a specific fertilizer, concentration, and irrigation method to best fit a specific producer's conditions.

Results obtained in these studies provide more information into irrigation and fertilization greenhouse forcing parameters for $O$. regnellii and $O$. triangularis. Because these oxalis plants are marketed mostly for their foliage, it is imperative for oxalis growers to produce the fullest, greenest or reddest, and blemish-free plants as possible.

\section{Conclusions}

Current $21 \mathrm{~N}-2.2 \mathrm{P}-16.6 \mathrm{~K}$ and $14 \mathrm{~N}-4.2 \mathrm{P}-$ $11.6 \mathrm{~K}$ fertilizer recommendations produced commercially acceptable plants, although larger and potentially more valuable $O$. regnellii and $O$. triangularis plants were produced using the $15 \mathrm{~N}-2.2 \mathrm{P}-12.5 \mathrm{~K}$ and $20 \mathrm{~N}-$ $1.3 \mathrm{P}-15.8 \mathrm{~K}$ fertilizer formulations, although they were not always significantly different from other fertilizer formulations. Results from the nutrient analysis suggest $\mathrm{Ca}, \mathrm{Mg}$, $\mathrm{Fe}$, and $\mathrm{Mn}$ have the greatest influence on quality growth and development of $O$. regnellii when using many standard commercial formulations. This is supported by the fact the best performing fertilizers, $15 \mathrm{~N}-2.2 \mathrm{P}-12.5 \mathrm{~K}$ and $20 \mathrm{~N}-1.3 \mathrm{P}-15.8 \mathrm{~K}$, both had extra macro- and micronutrients. Fertilizers containing little or no $\mathrm{P}$ should be avoided because oxalis leaf growth and plant size were drastically decreased and at the same time, fertilizers with excessive $P$ should be avoided so as to limit any detrimental effects associated with $\mathrm{P}$ nutrient leaching and runoff.

\section{Literature Cited}

Barker, A.V. and H.A. Mills. 1980. Ammonium and nitrate nutrition of horticultural crops. Hort. Rev. 2:395-425.
Biernbaum, J. 1997. Selecting blended water-soluble fertilizers. Greenhouse Product News 7:23$25,29$.

Brickell, C. and J. Zuk. (eds.). 1996. A-Z encyclopedia of garden plants. DK Publishing, USA. p. 72-73.

Cabrera, R.I. 1997. Comparative evaluation of nitrogen release patters from controlled-release fertilizers by nitrogen leaching analysis. HortScience 4:669-673.

Comerro, H.K. and G. Briggs. 2000. Effects of leaflet orientation on transpiration rates and water potentials of Oxalis montana. SUNY Geneseo Jour. Sci. Math. 1:7-10.

De Hertogh, A.A. 1996. Oxalis, p. C-133-C-145. Holland bulb forcer's guide. International FlowerBulb Centre, The Netherlands.

De Hertogh, A.A. and M. Le Nard. 1993. Oxalis, p. 764-767. In: De Hertogh, A.A. and M. Le Nard (eds.). The physiology of flower bulbs. Elsevier, Amsterdam, The Netherlands.

Dole, J. and H.F. Wilkins. 2005. Oxalis, p. 714 720 . Floriculture; principles and species. PrenticeHall, Upper Saddle River, NJ.

Dole, J.M., J.C. Cole, and S.L. von Broembsen. 1994. Growth of poinsettias, nutrient leaching and water-use efficiency respond to irrigation methods. HortScience 29:858-864.

Elliot, G. 1990. Reduce water and fertilizer with ebband-flow. Greenhouse Grower 8:70-72, 74-75.

Frett, J.J., M.A. Dirr, and A.M. Armitage. 1985. Nitrogen and calcium requirements of petunia hybrid 'Coral Sea'. Sci. Hort. 26:351-359.

Haley, T.B. and D.W. Reed. 2004. Optimum potassium concentration in recirculating subirrigation for selected greenhouse crops. HortScience 9:1441-1444.

Hall, B.J. 1980. The nuts and bolts of drip. Amer. Veg. Grower. 28:8-9.

Hammer, P.A. 2006. Oxalis. GrowerTalks 70(1):72. Hansen, C.W. and K.L. Nielsen. 2001. Reduced phosphorus availability as a method to reduce chemical growth regulation and to improve plant quality. Plant Nutr. 92:314-315.

Harbaugh, B.K., C.D. Stanley, and J.F. Price. 1986 Interactive effects of trickle irrigation rates, cultivars, and culture on cut chrysanthemum. HortScience 21:94-95.

Haver, D.L. and U.K. Schuch. 1996. Production and postproduction performance of two New Guinea Impatiens cultivars grown with 
controlled-release fertilizer and no leaching. J. Amer. Soc. Hort. Sci. 5:820-825.

Holcomb, E.J., S. Gamez, D. Beattie, and G.C. Elliott. 1992. Efficiency of fertigation programs for Baltic Ivy and Asiatic Lily. HortTechnology 1:43-46.

James, E.C. and M.W. van Iersel. 2001. Fertilizer concentration affects growth and flowering of subirrigated petunias and begonias. HortScience 36:40-44.

Kang, J.G. and M.W. van Iersel. 2001. Interaction between temperature and fertilizer concentration affects growth and flowering of sub-irrigated petunias and begonias. J. Plant Nutr. 24:753-765.

Kang, J.G. and M.W. van Iersel. 2002. Nutrient solution concentration affects growth of subirrigated bedding plants. J. Plant Nutr. 2:387-403.

Kang, J.G., M.W. van Iersel, and K.S. Nemali. 2004. Fertilizer concentration and irrigation method affect growth and fruiting of ornamental pepper. J. Plant Nutr. 27:867-884.

Kent, M.W. and D.W. Reed. 1996. Nitrogen nutrition of New Guinea Impatiens 'Barbados' and Spathiphyllum 'Petite' in a subirrigation system. J. Amer. Soc. Hort. Sci. 121:816-819.
Klock-Moore, K.A. and T.K. Broschat. 1999. Differences in bedding plant growth and nitrate loss with a controlled-release fertilizer and two irrigation systems. HortTechnology 2:206209.

Lea-Cox, J.D., D.S. Ross, and K.M. Teffeau. 2001. A water and nutrient management planning process for container nursery and greenhouse production systems in Maryland. J. Environ. Hort. 4:230-236.

Marschner, H. 1995. Mineral nutrition of higher plants. 2nd Ed. Academic Press, San Diego, CA.

Masson, J., N. Tremblay, and A. Gosselin. 1991 Nitrogen fertilization and HPS supplementary lighting influence vegetable transplant production. I. Transplant growth. J. Amer. Soc. Hort. Sci. 116:594-598.

Medina, L.C., T.A. Obreza, J.B. Sartain, and R.E. Rouse. 2008. Nitrogen release patterns of mixed controlled-release fertilizer and its components. HortTechnology 18:475-480.

Nelson, P., C.Y. Song, and J.S. Huang. 2002. What really causes stretch? Greenhouse Product News 12:24-28.
Nelson, P.V. 1994. Fertilization, p. 151-176. In: Holcomb, E.J. (ed.). Bedding plants IV. Ball Publishing, Batavia, IL.

Poole, R.T. and C.A. Conover. 1992. Fertilizers and medium affect foliage plant growth in an ebb and flow irrigation system. J. Environ. Hort. 10:81-86.

Reed, D.W. (eds.). 1996. Water, media, and nutrition for greenhouse crops. Ball Publishing, Batavia, IL.

Rideout, J.W. and L.F. Overstreet. 2003. Phosphorus rate in combination with cultural practices reduces excessive growth of tomato seedlings in the float system. HortScience 38:524-528.

Todd, N.M. and D.W. Reed. 1998. Characterizing salinity limits of New Guinea Impatiens in recirculating subirrigation. J. Amer. Soc. Hort. Sci. 123:156-160.

Uva, W.L., T.C. Weiler, and R.A. Milligan. 1998. A survey on the planning and adoption of zero runoff subirrigation systems in greenhouse operations. HortScience 33:193-196.

Yelanich, M.V. and J.A. Biernbaum. 1993. Root medium nutrient concentration and growth of poinsettia at three fertilizer concentrations and four leaching fractions. J. Amer. Soc. Hort. Sci. 118:771-776 